\title{
Cerebrospinal Fluid (CSF) Presepsin as a Diagnostic Marker for Bacterial Meningitis in Pediatric Intensive Care Units
}

Tarek Abd-Elrahman Attia ${ }^{1}$, Alaa Zedan Ibrahem ${ }^{1}$, Lamiaa Abd-Elwahab Mohamed ${ }^{2}$, Ahmed Mohamed Attia El-Bayed*1

Departments of ${ }^{1}$ Pediatrics, ${ }^{2}$ Clinical Pathology, Faculty of Medicine - Zagazig University, Egypt *Corresponding Author: Ahmed Mohamed Attia El-Bayed, E-mail: free_soul90@yahoo.com, Mobil: (+20) 01112336650

\begin{abstract}
Background: Meningitis is an inflammation of the leptomeninges. The inflammation may be caused by infection with viruses, bacteria, other micro-organisms, or non-infective causes.

Objective: The aim of this study was to evaluate the role of CSF-Presepsin in diagnosis of bacterial meningitis and in differentiation between bacterial and viral meningitis or aseptic meningitis.

Patients and methods: The present study was a cross sectional study conducted in Intensive Care Unit and Pediatric Departments of El-Hommyat Hospital in Zagazig in the period from January 2017 to November 2017. The study included 50 patient of children with age from 6 months to 14 years with symptoms of CNS infection. Among the studied subjects there were 30 cases already diagnosed as bacterial meningitis and 20 cases already diagnosed to have viral meningitis (controls). Full history, clinical examination, and full laboratory tests were taken (Complete blood count (CBC) with differential leukocytic count, random blood sugar, serum CRP, and CSF analysis, CSF presepsin (psp) and CRP).

Results: There was a significant increase in Presepsin and CRP in the CSF of cases of bacterial when compared to viral group. Additionally, there were significant direct correlation between CSF presepsin and CSF CRP to blood CRP, CSF total leucocytic count (TLC) and CSF protein and indirect correlation between CSF presepsin and hemoglobin level, platelet count and CSF glucose.

Conclusion: CSF-Presepsin and CSF-CRP can be used in diagnosis of bacterial meningitis and can differentiate between them in bacterial and viral patients.
\end{abstract}

Keywords: Meningitis, Cerebrospinal Fluid, Bacterial meningitis.

\section{INTRODUCTION}

Bacterial meningitis is a serious type of meningoencephalitis that causes inflammation of meninges of the brain, particularly the arachnoid and piamater. Apart from meningeal inflammation, it has also been shown to affect other regions of the central nervous system (CNS). It has serious complications for producing detrimental long-term clinical manifestations and life threatening consequences in comparison to aseptic meningitis ${ }^{(\mathbf{1}, \mathbf{2})}$.

Brain macrophage play an important role during inflammatory reactions of the central nervous system parenchyma, ventricles and meninges and are involved in the release of soluble CD14 ${ }^{(3)}$.

CD14 is a glycosylphosphatidylinositol(GPI)anchored glycoprotein expressed on the surface of monocytes/macrophages (mCD14) and serves as a receptor for complexes of lipopolysaccharides(LPS) and LPS-binding protein (LPBP) ${ }^{(4)}$. This activates a toll-like receptor 4 (TLR4) (specific proinflammtory signaling cascade) upon contact with infectious agent (5). CD14 is shed from the cell membrane into the circulation, forming sCD14 ${ }^{(6)}$.

Presepsin is a $13-\mathrm{KDa}$ protein, a truncated $\mathrm{N}$ terminal fragment of CD14 ${ }^{(7)}$. The production mechanisms of presepsin are related to the phagocytosis process and cleavage of membrane CD14 with lysosomal enzymes of granulocytes in response to bacterial infection ${ }^{(8)}$.

Determination of presepsin in CSF could overcome problems with time-consuming procedures in diagnosis and manegement of bacterial meningitis.

This study aimed to evaluate the role of CSF-Presepsin in diagnosis of bacterial and in differentiation between bacterial and viral meningitis.

\section{PATIENTS AND METHODS}

The present study was a cross sectional study conducted in Intensive Care Unit and Pediatric Departments of El-Hommyat Hospital in Zagazig in the period from January 2017 to November 2017. The study included 50 patients of children with age from 6 months to 14 years with symptoms of CNS infection. Among the studied subjects there were 30 cases already diagnosed as bacterial meningitis and 20 cases already diagnosed to have viral meningitis (controls). Full history, clinical examination, and full laboratory tests were taken such as CSF samples, C-reactive 
protein in blood, serum blood glucose and CBC with differential TLC.

Inclusion criteria: Age group of the patients (1 month - 14 years). Both sexes. Diagnosed as meningitis or suspected to be CNS infection.

Exclusion criteria: Patients outside the age group. Patient with hospital infections.

Written Informed consent was taken from the patients' parents to participate in the study.

\section{Ethical approval:}

Approval for performing the study was obtained from Pediatrics Departments, Zagazig University Hospitals after taking Institutional Review Board (IRB) approval. The work has been carried out in accordance with the code of ethics of the World Medical Association (Decleration of Helsinki) for studies involving humans.

Diagnosis of bacterial meningitis cases was based on full history taken, complete clinical examination including neurological findings (meningeal irriation signs), Bacteria isolated from CSF obtained via lumbar puncture and meningeal inflammation demonstrated by increased pleocytosis, elevated protein level and low glucose level in CSF. All these data undergo bacterial meningitis score for CDC/NHSN ${ }^{(9)}$.

CSF samples from cases and controls were examined for Presepsin levels using ELISA method (Sandwich technique). A CSF sample was commonly collected by performing a lumbar puncture, which is also known as a spinal tap. An analysis of the sample involves the measurement and examination for fluid pressure, proteins, glucose, red blood cells, white blood cells, chemicals, bacteria, viruses and other invasive organisms or foreign substances. It's performed by a doctor who is specially trained to collect CSF.

CRP was detected by latex agglutination method using commercial kit "Immunoscreen-CRP" by Monozyme.

\section{Statistical Analysis}

The collected data were computerized and statistically analyzed using SPSS program (Statistical Package for Social Science) version 16.0 (SPSS Inc., 2007). For the statistical calculations data coding was done. Qualitative (categorical) data were represented as frequencies and percentages, Chi- Square test $\left(\chi^{2}\right)$ and fisher exact test were carried out for testing the association between the qualitative data frequencies. Quantitative (numerical) data were represented as mean and standard deviation (SD) or median, student's t-test was used to detect difference between groups, which were normally distributed. MannWhitney test was used to detect the difference between groups, which were not normally distributed. The Pearson's correlation coefficients were used to estimate association between CSF persepsin level with clinical and laboratory data of studied patients. In order to assess the utility of CSF persepsin as a biomarker for bacterial meningitis in children, we compared the areas under receiver operating characteristic (ROC) curves between CSF persepsin and CRP using a $\left(\chi^{2}\right)$ test. The test results were considered significant when $\mathrm{p}$-value $\leq 0.05$, highly significant when $\mathrm{p}$-value $\leq 0.01$ and non-significant when $\mathrm{p}$-value $>0.05$. All $\mathrm{p}$ values are two-tailed.

\section{RESULTS}

Table (1): Blood laboratory measurements in studied groups

\begin{tabular}{|c|c|c|c|c|c|}
\hline & Parameters & Cases $(\mathrm{N}=30)$ & Control $(\mathrm{N}=\mathbf{2 0})$ & $t$ test & p value \\
\hline \multicolumn{6}{|c|}{ Total leucocytic count $\left(\right.$ cells $\left.\times 10^{3} / \mu \mathrm{l}\right)$} \\
\hline$\bullet$ & Mean \pm SD & $14.08 \pm 6.47$ & $6.09 \pm 0.96$ & 3.44 & 0.001* \\
\hline \multicolumn{6}{|c|}{ Hemoglobin (Hb) level(gm/dl) } \\
\hline$\bullet$ & Mean \pm SD & $10.25 \pm 1.25$ & $11.76 \pm 0.43$ & 5.10 & $<0.0001 * *$ \\
\hline \multicolumn{6}{|c|}{ Platelets count $\left(\times 10^{3} / \mu \mathrm{l}\right)$} \\
\hline$\bullet$ & Mean \pm SD & $208.9 \pm 63.23$ & $247.8 \pm 49.97$ & 2.31 & $0.025 *$ \\
\hline \multicolumn{6}{|c|}{ Serum glucose (mg/dl) } \\
\hline & Mean \pm SD & $96.57 \pm 8.08$ & $77.2 \pm 6.14$ & 3.03 & $0.004 * *$ \\
\hline
\end{tabular}

SD: Standard Deviation MW: Mann-Whitney U

** High statistically significant $(\mathbf{p}<0.01)$

*Statistically significant $(\mathbf{p}<0.05)$

Table (1) showed that there was a high statistical significant difference between cases and control group regarding blood laboratory measurements $(\mathrm{p}<0.001)$. Total leucocytic counts and serum glucose were significantly higher among cases group while hemoglobin and platelets were significantly lower among cases group compared to control group. 
Table (2): Cerebrospinal fluid (CSF) laboratory measurements in studied groups

\begin{tabular}{|c|c|c|c|c|}
\hline CSF & Cases $(\mathrm{N}=30)$ & Control $(\mathrm{N}=20)$ & t test & p value \\
\hline \multicolumn{5}{|l|}{ Glucose (mg/dl) } \\
\hline Mean \pm SD & $31.23 \pm 8.26$ & $77.2 \pm 7.41$ & 20.07 & $<0.0001 * *$ \\
\hline \multicolumn{5}{|l|}{ Protein (mg/dl) } \\
\hline Mean \pm SD & $187.1 \pm 5.95$ & $68.6 \pm 12.06$ & 9.81 & $<0.0001 * *$ \\
\hline \multicolumn{5}{|c|}{ Total leucocytic count $\left(\right.$ cells $\left.\times 10^{3} / \mu \mathrm{l}\right)$} \\
\hline Mean \pm SD & $1965.8 \pm 61.78$ & $40.8 \pm 8.69$ & 18.58 & $<0.0001 * *$ \\
\hline \multicolumn{5}{|l|}{ Lymphocytes } \\
\hline Mean \pm SD & $19.43 \pm 3.2$ & $46.2 \pm 3.75$ & 26.99 & $<0.0001 * *$ \\
\hline \multicolumn{5}{|c|}{ Polymorph Nuclear Leucocytes } \\
\hline Mean \pm SD & $80.57 \pm 3.21$ & $53.8 \pm 3.75$ & 26.99 & $<0.0001 * *$ \\
\hline
\end{tabular}

SD: Standard Deviation $\quad *$ Statistical significant $(\mathbf{p}<\mathbf{0 . 0 5}) \quad * *$ High statistical significant $(\mathbf{p}<\mathbf{0 . 0 1})$

Table (2) showed that there was a high statistical significant difference between cases and controls groups regarding CSF laboratory measurements $(p<0.01)$. Total leucocytic counts, polymorph nuclear leucocytes and protein were significantly higher among cases group while glucose and lymphocytes were significantly lower among cases group compared to control group.

Table (3): Comparison of C-reactive protein measurement in blood and CSF of studied groups

\begin{tabular}{|c|c|c|c|c|}
\hline Variable & Cases (N=30) & Control (N=20) & MW test & p value \\
\hline \multicolumn{5}{|c|}{ Serum CRP (mg/l) } \\
\hline $\begin{array}{l}\text { Mean } \pm \text { SD } \\
\text { Median }\end{array}$ & $\begin{array}{c}29.8 \pm 6.18 \\
24\end{array}$ & $\begin{array}{c}7.5 \pm 1.68 \\
6\end{array}$ & 20.07 & $<0.0001 * *$ \\
\hline \multicolumn{5}{|c|}{ CSF CRP (mg/l) } \\
\hline $\begin{array}{l}\text { Mean } \pm \text { SD } \\
\text { Median }\end{array}$ & $\begin{array}{c}45.4 \pm 3.5 \\
36\end{array}$ & $\begin{array}{c}2.20 \pm 0.52 \\
1.37\end{array}$ & 5.95 & $<0.0001 * *$ \\
\hline
\end{tabular}

SD: Standard Deviation $\quad$ MW: Mann-Whitney U $\quad * *$ High statistical significant $(\mathbf{p}<\mathbf{0 . 0 1})$

Table (3) showed that both blood and CSF CRP were statistically higher among cases than control group (p < $0.01)$.

Table (4): Level of CSF persepsin among studied groups

\begin{tabular}{||l|c|c|c|c|}
\hline \multicolumn{1}{|c|}{ Parameters } & Cases $(\mathbf{N}=\mathbf{3 0})$ & Control $(\mathbf{N}=\mathbf{2 0})$ & t test & p value \\
\hline CSF persepsin (mg/l) & $\begin{array}{c}2.58 \pm 0.90 \\
2.54\end{array}$ & $\begin{array}{c}0.54 \pm 0.14 \\
0.54\end{array}$ & 9.98 & $<\mathbf{0 . 0 0 0 1 * *}$ \\
\hline Mean \pm SD & Median &
\end{tabular}

Table (4) showed that mean CSF persepsin was significantly higher among cases compared to control group $(\mathrm{p}<$ $0.01)$.

Table (5): Accuracy of CSF persepsin at cut off value $\geq 0.744(\mathrm{mg} / \mathrm{l})$ in diagnosis of bacterial meningitis in children

\begin{tabular}{|l|l|c|c|c|}
\hline \multirow{2}{*}{ CDC score } & \multicolumn{2}{|c|}{ Meningitis } & \multirow{2}{*}{ Total } \\
\cline { 3 - 4 } CSF persepsin & Cases & \multirow{2}{*}{ Controls } & \\
\hline $\mathbf{0 . 7 4 4}$ & Positive & 30 & 1 & 31 \\
\hline$<\mathbf{0 . 7 4 4}$ & Negative & 0 & 19 & 19 \\
\hline Total & 30 & 20 & 50 \\
\hline
\end{tabular}

Table (5) showed that at $95 \%$ confidence interval, there were Sensitivity $=30 / 30 * 100=100 \% \quad 88.65-\quad 100$, Specificity $=19 / 20 * 100=95 \% \quad 76.39-99.11$, Positive Predictive value $(\mathbf{P P V})=30 / 31 * 100=96.8 \% \quad 83.81-$ 99.43, Negative Predictive value $(\mathbf{P N V})=19 / 19 * 100=100 \% \quad 83.18-100$ and Accuracy $=30+19 / 50 * 100=$ $98 \% \quad 89.5-99.65$. 
Table (6): Pearson's correlations between CSF persepsin level and clinical and laboratory data of studied patients $(\mathrm{n}=68)$

\begin{tabular}{|l|c|c|}
\hline \multicolumn{1}{|c|}{ Parameter } & r & p value \\
\hline Hb level & -0.697 & $<\mathbf{0 . 0 0 0 1} * *$ \\
\hline Blood total leucocytic count (TLC) & 0.25 & 0.08 \\
\hline Platelets count & -0.41 & $\mathbf{0 . 0 0 3} * *$ \\
\hline Serum glucose & 0.25 & 0.08 \\
\hline Blood CRP & 0.83 & $<\mathbf{0 . 0 0 0 1} * *$ \\
\hline CSF CRP & 0.95 & $<\mathbf{0 . 0 0 0 1} * *$ \\
\hline CSF TLC & 0.97 & $<\mathbf{0 . 0 0 0 1} * *$ \\
\hline CSF glucose & -0.93 & $<\mathbf{0 . 0 0 0 1} * *$ \\
\hline CSF protein & 0.99 & $<\mathbf{0 . 0 0 0 1} * *$ \\
\hline Age & 0.29 & $\mathbf{0 . 0 4} *$ \\
\hline
\end{tabular}

Table (6) showed that there were high statistical significant direct correlation between CSF persepsin and blood CRP, CSF CRP, CSF TLC, CSF protein levels $(p<0.01)$ and age $(p<0.05)$. However there was high statistical significant indirect correlation between CSF persepsin and $\mathrm{Hb}$ level, platelet count and CSF glucose levels $(\mathrm{p}<0.01)$. Meanwhile, it showed insignificant correlation with blood TLC and glucose $(\mathrm{p}>0.05)$.

\section{DISCUSSION}

Meningitis is an inflammation of the membranes that surround the brain and spinal cord. It is a common clinical problem during infancy and childhood. Delay in distinguishing between bacterial $\&$ viral meningitis \& treatment may have irrevocable consequences that lead to significant morbidity \& mortality. The initiation of proper medication in meningitis patients can often be delayed because of a lack of confidence in the presently available laboratory tests ${ }^{(\mathbf{1 0}, \mathbf{1 1})}$.

Most of the tests developed for the early diagnosis of meningitis are not sensitive and although some other tests are useful, they may not be affordable for routine use ${ }^{(12)}$. So, it is necessary to introduce simple, reliable and cost effective method for rapid diagnosis and differentiation of various types of meningitis ${ }^{(13)}$.

In the present study regarding blood measurments, there was a significant increase $(\mathrm{P}<$ 0.001 ) in the total leukocytic count (TLC) in bacterial meningitis cases $\left(14.08 \pm 6.47 \times 10^{3} / \mathrm{mm}^{3}\right)$ when compared to the control group $\left(6.09 \pm 0.96 \times 10^{3} / \mathrm{mm}^{3}\right)$. Total leucocytic counts and serum glucose were significantly higher among cases group while hemoglobin and platelets were significantly lower among cases group compared to control group. These observations are in agreement with Uddin et al. (14) whose study findings clearly indicated that TLC and PMNL had remarkably increased in pyogenic meningitis while lymphocyte count had increased more markedly in aseptic meningitis. This is supported by Fouad et al. (15) who observed that Leucocytosis $\left(>10,000 / \mathrm{mm}^{3}\right)$ was encountered in bacterial meningitis in $47.9 \%$ of patients, while only in $24.1 \%$ of patients with nonbacterial meningitis.
Also, in the present study, serum CRP in bacterial meningitis group was $29.8 \pm 26.18 \mathrm{mg} / \mathrm{L}$ and in control group was $7.5 \pm 2.68 \mathrm{mg} / \mathrm{L}$ with statistically significant increase in Serum CRP in bacterial meningitis cases when compared to control group $(\mathrm{P}<$ $0.01)$. These observations are in agreement with those of Thanoon $\boldsymbol{e t}$ al. ${ }^{(16)}$ who compared serum CRP in children with acute bacterial meningitis $(88.33 \pm 38.46$ $\mathrm{mg} / \mathrm{l})$ and a control group $(9.93 \pm 2.60 \mathrm{mg} / \mathrm{l})$ with a highly significant difference between the two groups $(\mathrm{P}<0.001)$. These results are supported by the observations of Mussa ${ }^{(17)}$ who found that serum CRP was positive in $82 \%$ of bacterial meningitis group and negative in $70 \%$ of the viral meningitis group, with sensitivity $82.14 \%$, specificity $73.17 \%$, positive predictive value $51.11 \%$ and negative predictive value $92.30 \%$ for diagnosis of bacterial meningitis.

Our study revealed significant decrease in CSF glucose in cases of bacterial meningitis (31.23 \pm $8.26 \mathrm{mg} / \mathrm{dl})$ when compared to control group $(77.2 \pm$ $7.41 \mathrm{mg} / \mathrm{dl})(\mathrm{P}<0.001)$. These observations are in agreement with those of Sarhat et al. ${ }^{(18)}$ and are supported by Jadali et al. ${ }^{(19)}$ who reported that CSF glucose in bacterial meningitis group was $21.3 \pm 17.5$ $\mathrm{mg} / \mathrm{dl}$, in viral meningitis group was $65.8 \pm 18.8 \mathrm{mg} / \mathrm{dl}$ and in control group was $72.3 \pm 11.8 \mathrm{mg} / \mathrm{dl}$ with significant decrease in the CSF glucose levels in the bacterial meningitis group compared to the other two groups ( $\mathrm{p}<0.001)$. Abro et al. ${ }^{(20)}$ observed that in comparison to the viral, the CSF glucose level was found to be lower in bacterial meningitis $(26.50 \pm$ $21.56 \mathrm{mg} / \mathrm{dl})$ than in viral meningitis group $(67.00 \pm$ $18.96 \mathrm{mg} / \mathrm{dl})$ with statistically significant difference (p value <.0001). Similarly, Uddin et al. ${ }^{(14)}$ stated that CSF glucose level decrease in pyogenic meningitis $(16-34 \mathrm{mg} / \mathrm{dl})$ but normal or increase in aseptic 
meningitis (46-72 mg/dl). Additionally, in the study of Khanam et al. ${ }^{(21)}$, the mean glucose was $23 \mathrm{mg} / \mathrm{dl}$ in the CSF of bacterial meningitis, while it was $53 \mathrm{mg} / \mathrm{dl}$ in aseptic meningitis. This is supported by Fouad $\boldsymbol{e} t$ $a l .{ }^{(15)}$ and Siddiqui \& Yohoshuva ${ }^{(22)}$.

More over, in the present study, there was significant increase in CSF protein levels in bacterial meningitis cases $(187.1 \pm 52.95 \mathrm{mg} / \mathrm{dl})$ when compared to the control group $(68.6 \pm 12.06 \mathrm{mg} / \mathrm{dl})$ $(\mathrm{P}<0.0001)$. These observations agree with those of Jadali et al. ${ }^{\left({ }^{(9)}\right)}$ who reported that CSF protein was $295 \pm 204.4 \mathrm{mg} / \mathrm{dl}$ in bacterial meningitis group, $57.5 \pm$ $51.9 \mathrm{mg} / \mathrm{dl}$ in viral meningitis group and $19.4 \pm 5.87$ $\mathrm{mg} / \mathrm{dl}$ in the control group. The differences in the mean values were statistically significant for CSF protein levels between both the bacterial meningitis group and the control group $(\mathrm{p}<0.0001)$.

Further more, in our study, CSF cell count was $1965.8 \pm 461.78 \mathrm{cells} / \mu \mathrm{l}$ in bacterial meningitis group and $40.8 \pm 8.69 \mathrm{cells} / \mu \mathrm{l}$ in the control group. There was significant differences in the CSF cell count of the study groups $(\mathrm{p}<0.0001)$ where polymorph nuclear leucocytes were significantly higher among cases group while lymphocytes were significantly lower among cases group compared to control group. These observations agree with those of Jadali $\boldsymbol{e t}$ al. ${ }^{(19)}$ who observed that CSF cells in bacterial meningitis cases was $3698 \pm 3003.1 \mathrm{cell} / \mathrm{mm}^{3}$, while it was $2.03 \pm 1.9$ cell $/ \mathrm{mm}^{3}$ in the control group. The differences in the mean value was statistically significant for CSF leukocyte count between both the bacterial and the control group ( $\mathrm{p}<0.001)$. Also, Abro et al. ${ }^{(20)}$, observed that the CSF leukocyte count was higher with predominant polymorphs $(95 \%)$ in bacterial than viral $(7 \%)$ cases (p value < .0001). This is supported by Khanam et al. ${ }^{(21)}$, who detected that in the CSF of bacterial meningitis, the mean leukocyte count was $4064 / \mathrm{mm}^{3}$ with PMN (85\%) while, in aseptic meningitis the mean leukocyte count was $148 / \mathrm{mm}^{3}$ with PMNL (19\%). This also is in accordance with the results of Fouad et al. ${ }^{(15)}$, who reported that in patients with bacterial meningitis, $67.4 \%$ had a CSF leukocyte count in the range of $>100-1,000 \mathrm{cell} / \mathrm{mm} 3$ and $32.6 \%$ had a leukocyte count $>1,000$ cell $/ \mathrm{mm} 3$. Patients with bacterial meningitis had a predominantly neutrophilic CSF where neutrophil percentage was > $50 \%(69.4 \%)$. On the other hand, patients with nonbacterial meningitis had a predominantly lymphocytic CSF in $76.5 \%$ of cases.

In the present study, CSF-CRP was measured in both bacterial $(45.4 \pm 30.5 \mathrm{mg} / \mathrm{L})$ and control group $(2.20 \pm 1.52 \mathrm{mg} / \mathrm{L})$. Our results showed highly significant difference in CSF-CRP between bacterial meningitis cases and control group $(\mathrm{P}<0.001)$ where cut off value of CSF-CRP for diagnosis of bacterial meningitis was $\geq 5.25 \mathrm{mg} / \mathrm{L}$ with sensitivity $100 \%$, specificity $95 \%$, positive predictive value $96.8 \%$, negative predictive value $100 \%$ and accuracy $98 \%$ with area under the curve (0.999). These results are in agreement with those of Jadali et al. ${ }^{\left({ }^{19)}\right.}$ who reported that CSF-CRP titration was positive in 32 out of 45 cases of bacterial meningitis with $84 \%$ sensitivity, $100 \%$ specificity, $100 \%$ positive predictive value, $88 \%$ negative predictive value and $93 \%$ efficacy. Also, the results of the present work are in accordance with that of Ćorić (23) who found that CSF-CRP was significantly increased in $95 \%$ of bacterial meningitis cases with mean CSF-CRP $21.4 \mathrm{mg} / \mathrm{l}$, while it was $0.25 \mathrm{mg} / \mathrm{l}$ in the control group.

In the present study, presepsin in the cerebrospinal fluid was also measured in bacterial meningitis and viral meningitis (control groups) where it was $2.58 \pm 0.90 \mathrm{mg} / \mathrm{l}$ and $0.54 \pm 0.14 \mathrm{mg} / \mathrm{l}$ successively.

Our results showed highly significant difference in CSF-PSP between bacterial meningitis cases and control group $(\mathrm{P}<0.001)$ where cut off value of CSF-PSP for diagnosis of bacterial meningitis was $\geq 0.744 \mathrm{mg} / \mathrm{l}$ with sensitivity $100 \%$, specificity $95 \%$, positive predictive value $96.8 \%$, negative predictive value $100 \%$ and accuracy $98 \%$ with area under the curve 0.933 . These results are in agreement with those of Nockher et al. ${ }^{(3)}$ who reported that CSFPSP titration was positive $(2.4 \pm 1.4 \mathrm{mg} / \mathrm{l})$ in cases of bacterial meningitis compared to viral meningitis, encephalitis and control groups $(0.87 \pm 0.57,0.51 \pm$ 0.13 and $0.19 \pm 0.06 \mathrm{mg} / \mathrm{l}$ respectively). The differences in the mean values were statistically significant for CSF presepsin (sCD14) between both the bacterial and other groups $(\mathrm{p}<0.001)$. Similarly, the present work agrees with Stubljar et al. ${ }^{\left({ }^{(6)}\right.}$ who reported that the sCD14-ST value was elevated in all critically ill patients with microbiologically proven infection independent of the bacteria isolated $(2,403.08 \pm 2,407.56 \mathrm{pg} / \mathrm{ml} ; \mathrm{P}<0.001)$. The best cutoff for presepsin for positive infection in CSF would be $625 \mathrm{pg} / \mathrm{ml}$. The best diagnostic accuracy for meningitis and ventriculitis was achieved with presepsin in CSF with areas under the curve (AUCs) of 0.877 (95\% confidence interval (CI), 0.793 to $0.961)$ sensitivity and specificity were $84.2 \%$ and $82.1 \%$ for SCD14-ST.

The present study show that there were high statistical significant direct correlation between CSF persepsin and blood CRP, CSF CRP, CSF TLC and CSF protein levels $(\mathrm{p}<0.01)$ and age $(\mathrm{p}<0.05)$. However there were high statistical significant indirect correlation between CSF persepsin and $\mathrm{Hb}$ level and platelet count and CSF glucose levels $(p<0.01)$. However, it showed insignificant correlation with blood TLC and glucose ( $p>0.05)$. This agrees with Stubljar et al. ${ }^{(6)}$ who reported that leukocytes and proteins in CSF were elevated in patients who had microbiologically confirmed infection $(\mathrm{P}<0.001$ and 
$P=0.001$, respectively). The best diagnostic accuracy for meningitis and ventriculitis was achieved with presepsin and proteins in CSF, with areas under the curve (AUCs) of 0.877 (95\% confidence interval (CI), 0.793 to 0.961 ) and 0.857 (95\% CI, 0.749 to 0.964$)$.

\section{CONCLUSION}

CSF-Presepsin and CSF-CRP can be used in diagnosis of bacterial meningitis and can differentiate between them in bacterial and control or viral patients. Additionally, there was a significant correlation between CSF-CRP level and CSF-presepsin levels and between either of them and all of TLC in the peripheral blood, CSF glucose, CSF protein and CSF cell count.

\section{RECOMMENDATIONS}

CSF presepsin is a good tool in diagnosis of bacterial meningitis. Another studies should be done on large scale to support our results.

\section{REFERENCES}

1. Hoffman O, Weber RJ (2009): Pathophysiology and treatment of bacterial meningitis. Ther Adv Neurol Disord., 2 (6): 1-7.

2. Bamberger DM (2010): Diagnosis, initial management and prevention of meningitis. Am Fam Physician, 82 (12): 1419-98.

3. Nockher WA, Wick M, Pfister HW (1999): Cerebrospinal fluid levels of soluble CD14 in inflammatory and non-inflammatory diseases of the CNS: upregulation during bacterial infections and viral meningitis. J neuroimmunol., 101 (2): 161-9.

4. Thorgersen EB, Pischke SE, Barratt-Due A et al. (2013): Systemic CD14 inhibition attenuates organ inflammation in porcine Escherichia coli sepsis. Infection and Immunity, 81 (9): 3173-81.

5. Pugin J, Heumann D, Tomasz A et al. (1994): CD14 is a pattern recognition receptor. Immunity, 1 (6): 509-16.

6. Stubljar D, Kopitar AN, Groselj-Grenc M et al. (2015): Diagnostic accuracy of presepsin (sCD14-ST) for prediction of bacterial infection in cerebrospinal fluid samples from children with suspected bacterial meningitis or ventriculitis. J Clin Microbiol., 53 (4): 1239-44.

7. Okamura Y, Yokoi H (2011): Development of a pointof-care assay system for measurement of presepsin (sCD14-ST). Clinica Chimica Acta, 412 (23-24): 215761.

8. Yaegashi $\mathrm{Y}$, Shirakawa K, Sato $\mathrm{N}$ et al. (2005): Evaluation of a newly identified soluble CD14 subtype as a marker for sepsis. J Infect Chemother., 11 (5): 234-8.

9. C-DC/NHSN (2017): Surveillance Definitions for Specific Types of Infections 2017. Available at: https://vvwvv.cdc.gov/nhsn/ pdfs/ pscmanual/ 17pscnosinfdef_current.pd. 2017.

10. Agarwal NP, Chandak NH, Taori GM et al. (2002): Application of Mancini technique as a diagnostic test in CSF of tuberculous meningitis patients. Med Sci Monit., 8 (6): 95-8.

11. Kashyap RS, Kainthla RP, Biswas SK et al. (2003): Rapid diagnosis of tuberculous meningitis using the simple Dot ELISA method. Med Sci Monit., 9 (11): 1236.

12. Kashyap RS, Kainthla RP, Satpute RM et al. (2004): Differential diagnosis of tuberculous meningitis from partially treated cases of pyogenic meningitis by cell ELISA BMC Neurology, 4: 16-19.

13. Shinde AR, Ghorpade KS, Siddiqui AM (2015): A study of Cerebrospinal Fluid Adenosine deaminase and C-reactive protein in Bacterial, Tubercular and Viral meningitis. Asian J Biomed and Pharm Sci., 5 (44): 1518.

14. Uddin MB, Rahman M, Siddique AB (2009): Usefulness of CSF C-Reactive Protein in Differentiating Pyogenic and Aseptic Meningitis. J Teachers Associa., 22 (1): 78-81.

15. Fouad R, Khairy M, Fathalah W et al. (2014): Role of Clinical Presentations and Routine CSF Analysis in the Rapid Diagnosis of Acute Bacterial Meningitis in Cases of Negative Gram Stained Smears. J Trop Med., 14: 1-7

16. Thanoon IA, Khlaf MM, Oglah MK (2009): Assessment of C - reactive protein and Oxidative/Antioxidative Status in Children with Acute Bacterial Meningitis. Malaysian J Pharm Sci., 7 (1): $73-$ 81.

17. Mussa RF (2015): The Significance of Serum C reactive protein in Childhood Acute Meningitis. Med J Babylon., 12 (3): 730-8.

18. Sarhat ER, Alanee AH, Al-Noaemi YA (2007): Evaluation of creatine kinase activity in Cerbrospinal fluid of normal individuals and patients with meningitis. Tikrit Med J., 13 (1): 102-105.

19. Jadali F, Sharifi MM, JAR EA et al. (2007): CReactive protein and Lactate Dehydrogenase in Serum and Cerebrospinal Fluid in Rapid and Early diagnosis of Childhood Meningitis. Iran J. Child Neurology, 1 (4): 3745 .

20. Abro AH, Abdou AS, Ali H et al. (2008): Cerebrospinal fluid analysis - acute bacterial versus viral meningitis. Pak J Med Sci., 24 (5): 645-50.

21. Khanam R, Hanif M, Hoque MM et al. (2012): Role of CSF

C-Reactive Protein for the Differentiation of Bacterial Meningitis from Aseptic Meningitis in Children. Bangladesh J Child Health, 36 (3): 126-132.

22. Siddiqui MA, Yohoshuva A (2016): CSF and serum CRP in the diagnosis of pyogenic meningitis. J Med Allied Sci., 6 (1): 23-28.

23. Ćorić J (2012): Evaluation of high sensitivity C-reactive protein assay in cerebrospinal fluid on the Dimension RxL analyzer. J Health Sci., 2 (1): 13-16. 